\title{
Insects as Food - The Opinion of Latvian Consumers
}

\author{
Ilga Gedrovica
}

Department of Food Technology, Faculty of Food Technology, Latvia University of Life Sciences and Technologies, Jelgava, Latvia

\section{Email address:}

Ilga.Gedrovica@llu.lv

\section{To cite this article:}

Ilga Gedrovica. Insects as Food - The Opinion of Latvian Consumers. American Journal of Entomology. Vol. 3, No. 3, 2019 , pp. 56-60. doi: $10.11648 /$ j.aje.20190303.11

Received: April 11, 2019; Accepted: July 11, 2019; Published: August 5, 2019

\begin{abstract}
In Latvia people usually use animal products (most of all eggs, milk, meat and their products) as protein sources. An online survey was conducted to investigate Latvian consumers' opinion about insects and larvae as new high-protein food. The questionnaires were filled in by 1,892 respondents speaking in Latvian at the age between 14 and 64, with an average age of 42 years, and gender distribution - 71\% females and 29\% males. Inhabitants of Latvia (about four fifths of the respondents) know that people are allowed to use both insects and larvae for their diet, however, $35 \%$ of all respondents could not mention the exact species of insects and larvae that are fit for human consumption. The grasshoppers and crickets were the most known edible insects for Latvian inhabitants. About a half of the Latvian consumers were not ready to supplement their daily menu with edible insects and larvae though respondents changed their attitudes when they had learned that the use of insects and larvae was important for the future and played an important role in keeping their environment cleaner and more enjoyable. A relatively small number of people were ready to start eating insects at once. In order to adapt this unusual source of protein to the inhabitants of Latvia, insects and larvae must be processed in powder form and presented in such a way that the shape of insects or their any part (leg, wings, horns, etc.) are not visible and there is no indication of the origin of the product.
\end{abstract}

Keywords: Edible Insects, Entomophagy, Consumers’ Attitude

\section{Introduction}

Eating of insects is not very common in Western countries, while in the tropics insects are often a regular part of the diet $[1,2]$. For people in Latvia insects and larvae as food are not acceptable, insects as food products cause discomfort and associations with a defective product in our culture.

However, it is known that most edible insects provide sufficient energy and protein intake in the human diet, as well as they meet the amino acid requirements. Insects also have rich content of mono- and polyunsaturated fatty acids; they are rich in trace elements such as copper, iron, magnesium, manganese, phosphorus, selenium and zinc, as well as vitamins like riboflavin, pantothenic acid, biotin, and folic acid in some cases [3, 4]. Insects are nutritionally interesting material, and they may be included in a common diet of consumers in the EU countries in the near future $[4,5]$. The high environmental impact connected with meat production and the increase in demand until 2050 require dietary changes. Insect-based meat substitutes are potentially more sustainable [5-9].
Of course, this global topicality will also affect Latvia, but it is important to get to know the taste of the Latvian people in order to find the best approach to the integration of the recent trends into eating habits.

There is a similar situation in other countries where attempts have been made to introduce insects and larvae as raw materials. However, Latvia will face more challenges than the countries where there are already some insect eating traditions, for example, consumers in Western Kenia accept edible insects as food and as an alternative to conventional meat [10]. In addition, the Australian population have a neutral or positive attitude towards entomophagy [11].

The aim of the study was to obtain the information and to find out the opinion of Latvian consumers regarding such non-traditional high-protein food products as insects and larvae.

To achieve the aim the following objectives were set out: (a) to assess respondents' knowledge of different high-protein food products; (b) to identify respondents' attitudes towards the usage of non-traditional protein sources like insects and larvae in human food. 


\section{Methodology}

\subsection{Survey}

An online survey was conducted to investigate Latvian consumers' opinion regarding insects as food. The survey was carried out from January 2018 to February 2019 using electronic questionnaires and the Online survey creating tool VisiDati. lv.

An electronic survey consisted of 15 questions that covered topics such as the most commonly used high-protein food products, the respondents' knowledge of edible insects and larvae, their willingness to accept them and their attitude to non-traditional protein sources. The questionnaire was in Latvian and it was ensured that this questionnaires was filled in by Latvian speaking population. The total number of respondents was 1,892. The age of the respondents was between 14 and 64, with an average age of 42 years. The distribution of respondents by gender was: $29 \%$ males and $71 \%$ females.

The collected data were analysed; the means, standard deviation and percentage were calculated. In addition, this result was supported by the Chi-square test for non-parametric variables.

\subsection{Data Analysis}

All the data were collected and analysed via a combination of descriptive techniques (means, frequencies, percentages) using Microsoft Excel, including segmentation of consumers on the basis of factors such as the sex and age, and the analysis of variance (ANOVA) using software SPSS package 21.0.

\section{Results and Discussion}

\subsection{Protein Sources in Latvia}

Latvia is the country where most of protein is taken from animal products. Milk and dairy products, meat and meat products, eggs are popular as well, however, fish is not used so much as food.

The output of milk in 2016 was $503 \mathrm{~kg}$ per capita of which consumption per household member per year was 46.631 of milk, fermented milk products (12.78 1), sour cream $(11.83 \mathrm{~kg})$, yogurt $(7.30 \mathrm{~kg})$, cheese $(7.20 \mathrm{~kg})$, cottage cheese and curd $(6.97 \mathrm{~kg})$ [12].

The output of meat (slaughter weight) in 2016 was $44 \mathrm{~kg}$ per capita. Consumption of meat and meat products (average per household member per year 2016) was the following: sausage products and smoked meat $-20.71 \mathrm{~kg}$, pork $-19.07 \mathrm{~kg}$, poultry - $12.29 \mathrm{~kg}$, processed meat and prepared meat -6.83 $\mathrm{kg}$, edible offal, including smoked offal $-4.87 \mathrm{~kg}$, beef -1.36 $\mathrm{kg}$, game meat $-1.20 \mathrm{~kg}$, canned meat $-0.34 \mathrm{~kg}$, meat of sheep and goat $-0.22 \mathrm{~kg}$, and veal $-0.11 \mathrm{~kg}$ [12].

Consumption of fish and fish products (average per household member per year 2016) was small: fresh, chilled and frozen fish $-5.11 \mathrm{~kg}$, canned fish and processed fish-based prepared products $-2.51 \mathrm{~kg}$, herring and other salted fish -
$1.17 \mathrm{~kg}$, dried or smoked fish - $1.03 \mathrm{~kg}$, seafood - $0.15 \mathrm{~kg}$ [12].

As concerns plant protein in Latvia, people use peas and beans. Latvians are proud of their grey peas, which are always used for Christmas (due to traditions), but at other times very rarely. During the season Fava beans, snap beans and garden peas are popular among Latvian inhabitants. The total consumption of legumes in Latvia is very small - only $2.83 \mathrm{~kg}$ per capita [13]. The summarized results show that the consumption of the protein-containing products of the respondents is in accordance with the data of the Central Statistical Bureau of Latvia.

\subsection{Latvian Consumers' Knowledge About Protein Sources}

The respondents had to answer what protein sources they knew. Women had better knowledge than men because $59 \%$ of all the surveyed women could name both animal and vegetable protein sources, and only some women did not know this topic (Figure 1). Men (56\% of respondents) considered animal sources to be the source of protein, but there were quite a large number (13\% of respondents) of men who admitted that they did not know anything about proteins or did not think about food in these categories (Figure 1). Only a few questionnaires contained the answer that the source of protein might also be insects or larvae.

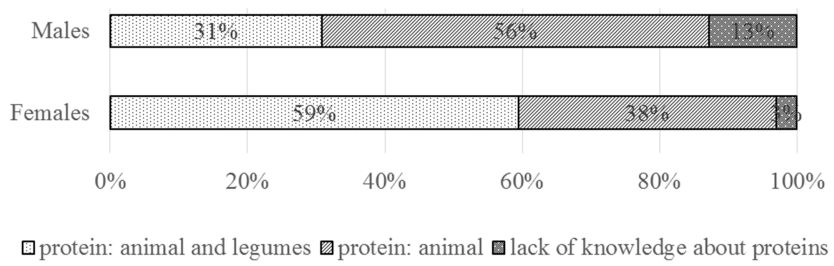

Figure 1. Respondents' knowledge about protein sources.

\subsection{Latvian Consumers' Knowledge About Edible Insects and Larvae}

Nowadays many people are interested in a healthy lifestyle and one of its important parts is nutrition. Information is obtained from newspapers, magazines, television, radio and, most of all, social networks. Family, friends, acquaintances and colleagues, professional activities and travelling are important sources of information since the information on edible insects and larvae has reached the inhabitants of Latvia, as about four fifths of the surveyed people know that both insects and larvae are allowed to be used in people's diet, although women are better informed (Figure 2). People in Latvia have noticed that insects are edible (the same does not refer to larvae) and that a cricket is a symbol of edible insects.

The answers regarding an opinion of people of Latvia why the world population has turned to consuming insects and larvae as food, show that only about a half of the respondents have competence about the processes taking in the world, the situation with the environment, the depletion of resources, etc. 


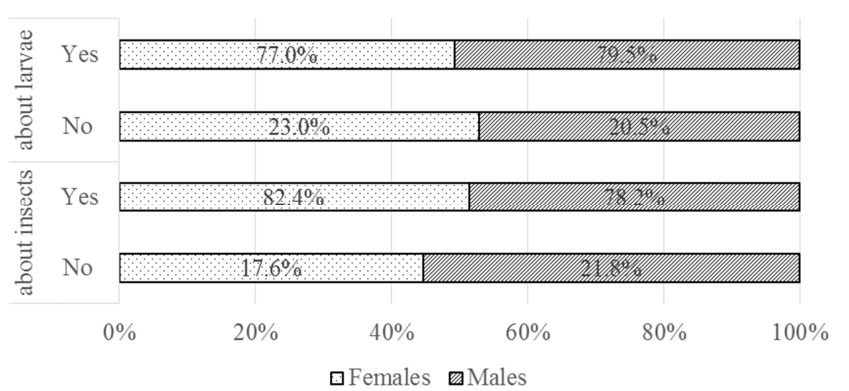

Figure 2. Respondents' answer to the question "Have you heard about edible insects / edible larvae?"

The answers to the question what non-traditional protein sources respondents can name may be divided into three parts for both men and women. One part of the respondents (34\% of women and $37 \%$ of men) were not aware of untraditional sources of protein. The second part of the respondents $(45 \%$ of women and $51 \%$ of men of all respondents) named an insect or larvae as untraditional protein source, but the majority of the responses (more than $80 \%$ ) included grasshoppers and crickets. Some surveyed people also named beetles, earthworms, cockroaches, silkworms, bamboo worms, spiders and scorpions. If it is known that more than 200 species can be used for human consumption [4, 8, 14], the Latvian population is not informed about such a wide range on offer. The last part of respondents $(21 \%$ of women and $12 \%$ of men) considered frogs, mice, rats, snakes, dogs, cats, snails, squid, shrimps, mussels, crustaceans, crabs, eggs, algae, stem cells, soya, amaranth, quinoa, lentils as untraditional protein sources.

\subsection{Attitude to Edible Insects and Larvae Usage in Food}

The respondents' answers show that Latvians are not responsive to the use of unusual high-protein products as food, because only $17 \%$ women and $27 \%$ have ever tasted them, for example, insects or larvae. In addition, $48.6 \%$ of women and $57.7 \%$ of men disliked the idea of integration of insects and larvae into human food and food production. The respondents who supported the introduction of alternative protein sources in Latvia explained their views as follows: "I am conservative, but I understand that I also have to change; if we need it ... then nothing else is left to do; I am not bothered by such innovations; the situation in the world with proteins and the environment would require such products for Latvia in the future; I'm always open to the new one; Every idea is considered; It would be good if such products were readily available in Latvia; If they taste good then I used it; If it's safe to use, then I'll try it; If it helps someone and is important then "yes"; I like different innovations, new ideas and suggestions; why not, there are many countries in the world where it happening for a long time; It would be good to have more information on this topic and products". People who did not like the idea of using insects and larvae in their diet mentioned the following reasons for rejection: "the use of insects and larvae in our region is not typical; if there is a wide choice of traditional protein rich products in Latvia, why such changes are needed; it does not affect me, it is for people who need it vitally and have no other option; I'm a vegetarian; it is more acceptable to me to use stem cells". Those who were not supportive or disapprove edible insects and larvae usage in human diet did not favour any side or supported this idea partially. The countries of origin of the insects and larvae products tasted by respondents were exotic destinations (Mexico, Thailand, Vietnam, Korea, Malaysia, Zimbabwe, Cambodia) where they had been for holidays. The main reasons why Latvian people agreed to taste edible insects and larvae were mostly "the satisfaction of curiosity, just for fun, just for joke, to show off in front of friends"; these answers were suggested mainly by men in young age. Some people always search for something new, also in food, therefore they ordered these unusual high-protein products through the online stores to satisfy their own curiosity.

\subsection{Acceptance to Edible Insects and Larvae Usage in Food}

About a half of the Latvian consumers are not ready to supplement their daily menu with edible insects and larvae (Figure 3). 55\% of women did not accept the use of insects in their daily diet. Some respondents said they were ready to become vegetarians so that they would not have to eat larvae or insects. Latvians are prejudiced towards insects as food because there is an opinion that insects and larvae are inedible things for humans or that they are associated with damaged products, because fresh products never contain larvae. $12 \%$ of surveyed men have not realized whether they are ready to eat insects and larvae on everyday basis because they have never tasted them; the taste would help them to understand if these high-protein products could be included in the daily menu.

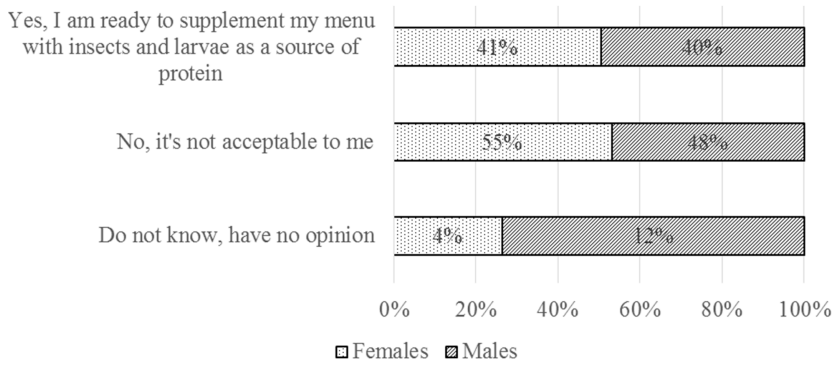

Figure 3. Latvian consumers' willingness include edible insects and larvae in their daily diet.

It seems unusual and fun for people in Europe to watch inhabitants of Asia or other non-European countries eating, for example, beetles, scorpions or ants gladly, but when a Latvian resident must make the choice of what to include in his/her diet from new products rich in protein, it is not an easy decision. Consumers' acceptance of certain food items is frequency identified as a significant barrier to adoption of insects as food source in population without a recent history of insects' consumption [15].

If it is necessary to make a choice, a Latvian consumer will better accept such insects as food (Figure 4, 32\% of women and $15 \%$ of men) which have positive associations in Latvian culture such as butterflies, bees, dragonflies etc. As regards 
larvae, in Latvian culture they are associated with the damaged product, for example, a larva in an apple is the reason to lose a desire to eat this apple. Also, a nut with a caterpillar is no longer desirable, but if this nut has been eaten accidentally, we feel a bitter taste. Small white larvae in raspberries, favourite Latvian summer berries, might spoil a delicious look of berries with pleasant fragrance. Latvians do not appreciate if a beautiful fungus found in the forest has small white larvae in it. The above mentioned attitude to larvae is certainly one of the reasons why more than a half (53\% of the respondents) of the women categorically refused to accept such innovations (Figure 4).

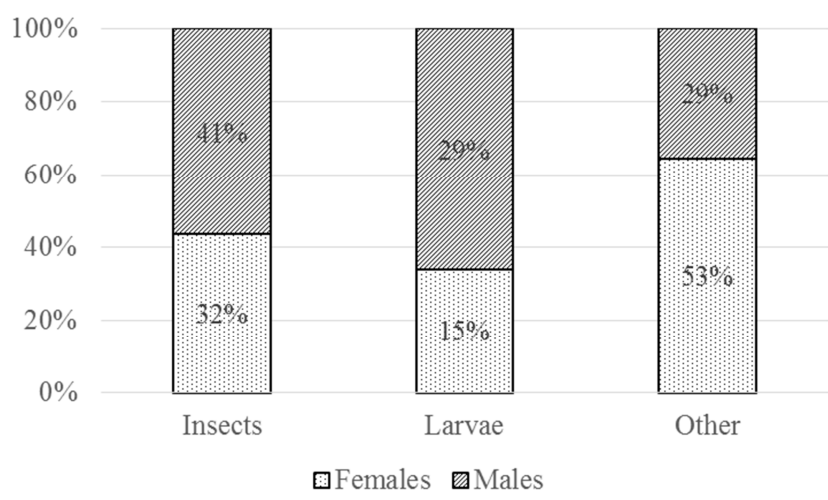

Figure 4. Latvian consumers' choice regarding edible insects and larvae as food.

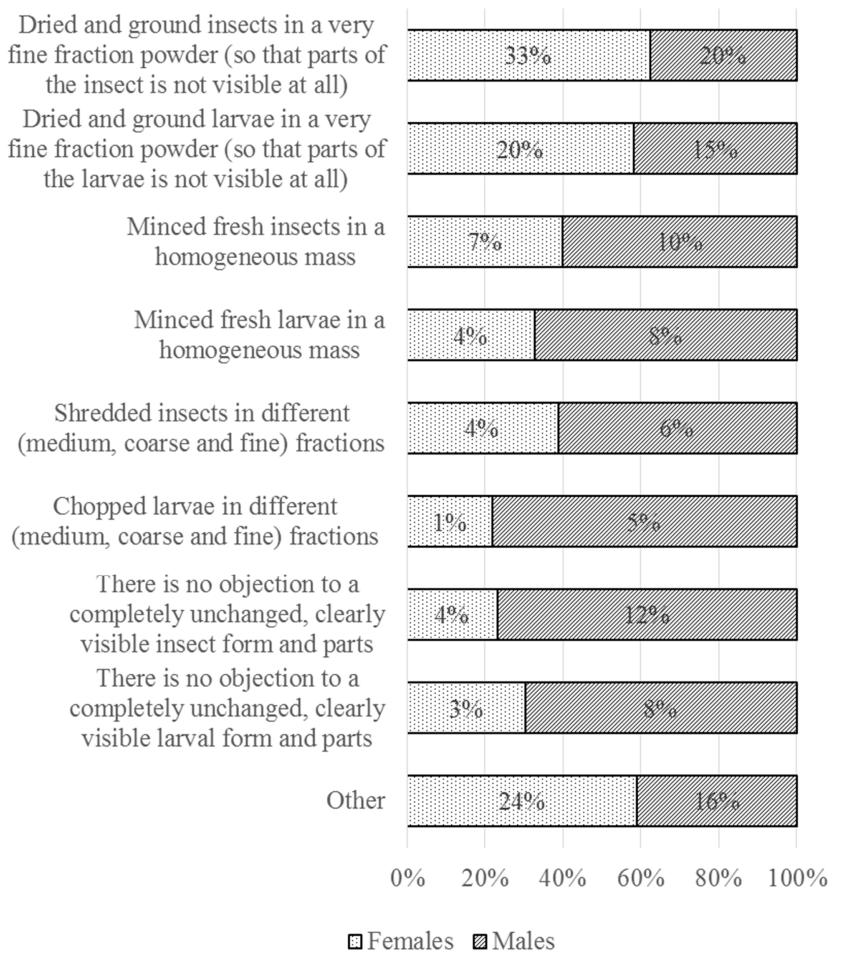

Figure 5. The best way of processing of insects and larvae in the opinion of Latvian consumers.

In order to adapt unusual sources of protein for the inhabitants of Latvia, insects and larvae preferably must be processed in powder form (consistent with the results of other studies [16]) and definitely in such a way that the shape of insects or their any part (leg, wings, horns, etc.) indicating the origin of the product (Figure 5) is not visible.

A relatively small number of people are ready to start eating insects (only $4 \%$ of women and $12 \%$ of men from all respondents) and larvae (only $3 \%$ of women and $8 \%$ of men from all respondents) which are completely unchanged with a clearly visible shape.

However, respondents changed their attitudes when they learned that the use of insects and larvae is important for the future of our planet and plays an important role in keeping the environment cleaner and more enjoyable. $31.8 \%$ of women were thoughtful about their current protein choices and could start using non-traditional protein-rich products in the near future.

Of all women, $13.3 \%$ would be willing to replace usual products with alternative protein sources, while $12.85 \%$ would reduce their use of usual protein sources. Nothing will change in their nutrition habits for $37.4 \%$ of men and $26.5 \%$ of women; such an opinion was mostly expressed by older respondents.

\section{Conclusions}

Latvian consumers are well-informed about the use of insects and larvae in the diet, and these unusual protein sources associate them mostly with grasshoppers and crickets. More than half of Latvians do not like the idea of integration of insects and larvae into human food and food production. They are not ready to supplement their daily menu with edible insects and larvae. Main reasons for rejection of insects and larvae usage in food are that: the use of insects and larvae in our region is not typical; there is a wide choice of traditional protein rich products in Latvia, for that reason sees no need for usage of insects in human diet; people believe that the ongoing global changes will not affect them; such changes are needed for people who need it vitally and have no other option. In the initial phase of introducing insects and larvae as food in Latvia, the most appropriate way of processing them would be drying and then grinding them into a fine fraction powder. The major reported barriers to edible insects and larvae consumption are little information available about the importance of alternative protein sources in human diet; their restricted availability and the lack of information about cooking methods and preparing of dishes.

\section{Acknowledgements}

Current research has been supported by the European Regional Development Fund under the activity "Post-doctoral Research Aid", project No 1.1.1.2/VIAA/1/16/190 "New sources of protein for food in Latvia".

\section{References}

[1] Van Huis, A. (2018) Insects as Human Food. Aviable at: https://www.researchgate.net/publication/322181280_Insects_ as Human Food. 
[2] Lang, E. (2013) Eating Insects. Eating insects as food. Edible insects and bugs, insect breeding, most popular insects to eat, cooking ideas, restaurants and where to buy insects all covered. IMB Publishing, 124.

[3] Rumpold, B. A., Schluter, O. K. (2013) Nutritional composition and safety aspects of edible insects. Molecular Nutrition\&Food Research 57, 802-823.

[4] Van Huis, A., Tomberlin, J. K. (2018) Insects as food and feed from production to consumtion. Wageningen Academic Publishers, 447.

[5] Janssen, R. H. (2018) Potential of insect proteins for food and feed. Effect of endogenous enzymes and iron-phenolic complexation. Thesis for the degree of doctor at Wageningen University, 146 Aviable at: http://edepot.wur.nl/445811.

[6] Kourimska, L., Adamkova, A. (2016) Nutrition and sensory quality of edible insects. NFS Journal 4: 22-26.

[7] Smetana, S., Mathys, A., Knock, A., Heinz, V. (2015) Meat alternatives: life cycle assessment of most known meat substitutes. The International Journal of Life Cycle Assessment 20: $1254-1267$.

[8] Dossey, A. T., Morales-Ramos, J. A., Rojas M. G. (2016) Insects as Sustainable Food Ingredients. Production, Processing and Food Applications. Academic Press, 385 Aviable at:

https://www.researchgate.net/profile/Jeffery_Tomberlin/public ation/304714699_Insect_Mass_Production_Technologies/link $\mathrm{s} / 59 \mathrm{cc} 8 \mathrm{c} 0 \mathrm{aaca} 27 \overline{\mathrm{b} b 050 \mathrm{fb}} 291 / \overline{\mathrm{I}}$ sect-Mass-Production-Techn ologies.pdf.

[9] Martin, D. (2014) Edible: An Adventure into the World of Eating Insects and the Last Great Hope to Save the Planet. New Harvest Houghton Mifflin Harcourt, Boston, New York, 251.

[10] Pambo, K. O., Okello, J. J., Mbeche, R., Kinyuru, J. N. (2016) Consumer Acceptance of Edible Insects for Non-Meat Protein
in Western Kenya.
fs.semanticscholar.org/d839/c
Aviable
at: https://pdfs.semanticscholar.org/d839/dc4dbbe677d84d5bb83 daf109b1b3862ad0b.pdf.

[11] Wilkinson, K., Muhlhausler, B., Motley, C., Crump, A., Brau, H., Ankeny, R. (2018) Australian Consumers' Awareness and Acceptance of Insects as Food. Insects, 9 (2), 44.

[12] Central Statistical Bureau of Latvia (2019) Consumption of food products 2016. Aviable at:

https://www.csb.gov.lv/en/statistics/statistics-by-theme/socialconditions/household-budget/key-indicator/consumption-food -products.

[13] Central Statistical Bureau of Latvia (2019) Statistical Yearbook of Latvia 2018. Aviable at:

https://www.csb.gov.lv/sites/default/files/publication/2018-12/ $\mathrm{Nr}$ 01 Latvijas statistikas gadagramata 2018 Statistical\%20 Yearbook\%20of $\% 20$ Latvia_\%2818_00\%29_LV_EN.pdf.

[14] Jongema, Y. (2017) Worldwide list of recorded edible insects. Aviable at:

https://www.wur.nl/upload_mm/8/a/6/0fdfc700-3929-4a74-8b 69-f02fd35a1696_Worldwide $\% 201$ ist $\% 20$ of $\% 20$ edible $\% 20$ ins ects\%202017.pdf.

[15] Payne, C. L. R., Dobermann, D., Forkes, A., House, J., Josephs, J., McBride, A., Muller, A., Quilliam, R. S., Soares, S. (2016) Insects as food and feed: European perspectives on recent research and future. Journal of Insects as Food and Feed. 2 (4): 269-276 Aviable at: https://www.wageningenacademic.com/doi/pdf/10.3920/JIFF2 016.0011 .

[16] Wendin, K., Norman C., Forsberg, S., Davidsson, F., Josell, A., Langton, M., Prim, M., Berg, J. (2017) Insects as a Culinary Ingredient - Consumer Acceptance and Neophobia. Aviable at: https://www.researchgate.net/publication/319351086_Insects as_a_Culinary_Ingredient_-_Consumer_Acceptance_and_Neo phobia. 